\title{
Executive directors in business rescue: employees or something else?
}

\section{EP Joubert}

$L L B$ LLM

Lecturer in Mercantile Law, University of Pretoria

\author{
A Loubser \\ LLB LLM LLD \\ Professor of Mercantile Law, University of South Africa
}

\section{OPSOMMING}

Uitvoerende direkteure in ondernemingsredding: werknemers of iets anders?

\begin{abstract}
Die Maatskappywet 71 van 2008 verleen uitgebreide magte en regte aan die werknemers van 'n maatskappy wat in ondernemingsredding verkeer. Afgesien van die regte wat aan die werknemers verleen word in hul hoedanigheid as geaffekteerde persone en as moontlike skuldeisers vir onbetaalde vergoeding, verkry hulle ook spesiale regte bloot weens die feit dat hulle werknemers is. Daar bestaan voldoende gesag vir die standpunt dat die uitvoerende direkteure van 'n maatskappy ook werknemers van die maatskappy is. Die vraag wat in hierdie artikel aangespreek word is of uitvoerende direkteurs dus ook outomaties al die regte en magte verkry wat aan werknemers verleen word wanneer hul werknemer-maatskappy in ondernemingsredding geplaas word. Daar word gekyk na sommige van hierdie regte en magte en die effek wat dit op die ondernemingsredding kan hê.
\end{abstract}

\section{Introduction}

Although the Memorandum on the Objects of the Companies Bill, 2008 states that Chapter 6 of the proposed Act regulating business rescue proceedings would recognise the interests of shareholders, creditors and employees, emphasis was placed on the protection of the interests of workers' not only by recognising them as creditors if the company owed them money before commencement of the business rescue proceedings, but also by affording them specific rights to participate in the procedure simply by virtue of being employees.

It was thus to be expected that the rights of employees in this process would be extensive and entrenched throughout the whole of the business rescue proceedings. These rights stem from three sources in the Companies Act of $2008:^{2}$ the inclusion of employees in the definition of 'affected persons' who enjoy a wide array of powers and rights; their

1 Item 10 of the Memorandum on the Objects of the Companies Bill, 2008 attached to the Companies Bill, B61 D - 2008.

2 Act 71 of 2008 (hereafter the 'Companies Act').

How to cite: Joubert \& Loubser 'Executive directors in business rescue: employees or something else?' 
recognition as creditors where the company owes them any remuneration that was due before commencement of business rescue; and simply based on the fact that they are employees of the company. ${ }^{3}$

Section 128(1)(a) of the Companies Act defines an 'affected person' for purposes of business rescue proceedings as a shareholder or creditor of the company, as well as any registered trade union representing employees of the company, and any individual employee who is not represented by a trade union. Directors, in their capacity as such, are not included in this definition. However, executive directors are normally in the full-time employment of the company and are thus employees, albeit a special type of employee. Because they have not been specifically excluded from the definition of 'affected persons', or from enjoying any of the special rights and powers given to employees by Chapter 6 of the Companies Act, there is a strong argument that they also may benefit from the special position that employees enjoy during business rescue proceedings. Their inclusion may lead to a situation in which directors are able to exert much more influence on the process than would be desirable or was perhaps foreseen by the legislature.

The issue that will be addressed in this article is whether executive directors will, or should, be regarded as employees for purposes of business rescue proceedings and what the possible consequences could be if they enjoy all the special rights and privileges.

\section{The Distinction Between Executive and Non- executive Directors}

The King Report on Corporate Governance (King I) ${ }^{4}$ distinguished clearly between executive and non-executive directors ${ }^{5}$ while the King Report on Corporate Governance for South Africa 2002 (King II) further developed this distinction by listing the criteria according to which a director can be classified as an executive or a non-executive director. ${ }^{6}$ According to these criteria, an executive director is a person who is involved in the day-to-day management of the company and/or in the full-time salaried employment of the company or any of the subsidiaries of the company. A non-executive director is characterised by not being involved in the day-to-day management of the company. He or she is also not in the fulltime salaried employment of the company.

3 For a detailed discussion of the rights and powers afforded to employees in these three capacities, see Loubser $\&$ Joubert 'The role of trade unions and employees in South Africa's business rescue proceedings' 2015 ILJ 25.

4 Published in 1994 by the Institute of Directors.

5 King I Report 32-33 par 4.

6 In Principle 2.4.3., the King Report on Governance (King III Report) published in 2009 did not repeat these criteria but clearly incorporated them: see Loubser 'The King Reports on corporate governance' in Esser \& Havenga (eds) Corporate Governance Annual Review 2012 (2012) 35. 
In contrast to the King Reports, the Companies Act does not use the words 'executive' or 'non-executive' either in its definition of a director in section 1 or in sections 75 to 78 dealing with the duties and liabilities of directors. ${ }^{7}$ However, the Companies Act describes some directors in such a way that a distinct description of a particular director similar to that found in the King Reports can be implied. For example, section 94 of the Companies Act, that regulates the composition of audit committees, explicitly states that a director who is elected to serve on the audit committee must not be involved in the day-to-day-management of the company or be in the full-time employment of the company. ${ }^{8}$ Clearly, this section requires that only non-executive directors may be members of the audit committee.

Another example is found in Regulation 43(4) of the Companies Regulations ${ }^{9}$ where the composition of the Social and Ethics Committee is prescribed. This Regulation requires that at least one of the directors serving on this committee must be a director 'who is not involved in the day-to-day management of the company's business'. Again, the reference is to a non-executive director. It is clear, despite the fact that there is no express distinction between the various types of directors in the Companies Act, that the Act acknowledges that there is a difference. ${ }^{10}$

\section{Executive Directors as Employees}

Section 213 of the Labour Relations Act ${ }^{11}$ provides a wide definition of an employee and provides that 'employee' can be defined as:

(a) any person, excluding an independent contractor who works for another person or for the state and who receives, or is entitled to receive, any remuneration; and

(b) any other person who in any manner assists in carrying on or conducting the business of an employer. ${ }^{12}$

In PG Group (Pty) Ltd $v$ Mbambo NO and Others, Revelas J remarked that 'this definition would surely apply to most, if not all, directors'. ${ }^{13}$

The question whether executive directors qualify as employees of a company has been considered by the courts on many occasions when dealing with a director's dismissal from the company.

7 'Director' is defined in s 1 as follows: '.. a member of the board of a company, as contemplated in section 66 , or an alternate director of a company and includes any person occupying the position of a director or alternate director, by whatever name designated'.

8 S 94(4)(b) of the Companies Act.

9 Companies Regulations, 2011.

10 Loubser \& Joubert supra $\mathrm{n} 3$ at 25.

11 Act 66 of 1995 (hereafter the 'Labour Relations Act').

12 S 213 of the Labour Relations Act.

13 PG Group (Pty) Ltd $v$ Mbambo NO \& Others [2004] ZALC 78 par 24. 
In Chillibush Communications (Pty) Ltd $v$ Johnston \& Others $^{14}$ the Labour Court held that there was convincing authority confirming that a director could, and very often would, be an employee of the company and would be governed by the Labour Relations Act in this capacity as opposed to the Companies Act that regulated the director in his or her capacity as a director. The court found strong support for this view in the $P G$ Group case.

The dual capacity of a person as director and employee was clearly illustrated in Amazwi Power Products (Pty) Ltd $v$ Turnbull ${ }^{15}$ where it was held that a person could resign as director but continue to be an employee.

In Protect $A$ Partner (Pty) Ltd $v$ Machaba-Abiodun ${ }^{16}$ the Labour Court once again had to decide on this matter. The court considered the definition of 'employee' in the Labour Relations Act and adopted the reality test that consists of the following aspects:

- The right of supervision and control of the employer over the employee;

- Whether or not the employee forms an integral part of the organisation; and

- The extent of financial dependence of the employee on the employer. ${ }^{17}$

The court emphasised the fact that not one single factor can be decisive, but that the control element weighed slightly more in determining an employment relationship. The court explained, in determining whether or not the employee formed part of the organisation, that one should consider whether the employee assists the employer in conducting its business. Due to the fact that a company is a juristic person, the only way the company can conduct business is through its organs, of which the board of directors is one. The court therefore found that Machaba- Abiodun, who was an executive director of the company, was an employee of the company.

One can thus say that when an executive director is dismissed it must be in terms of the provisions of the Labour Relations Act. ${ }^{18}$ This view is confirmed by section 71 of the Companies Act that provides for the removal from office of a director either by the passing of an ordinary resolution by the shareholders of the company or, in some instances, by a decision of the board. ${ }^{19}$

14 Chillibush Communications (Pty) Ltd v Johnston \& Others [2010] ZALC 3 par 24.

15 Amazwi Power Products (Pty) Ltd v Turnbull [2008] ZALAC 8 par 20.

16201334 ILJ 392 (LC).

17 Lumb \& Maharaj 'Directors - when are they considered to be employees' 2012 Lexology www.lexology.com/library/ (accessed 2014-09-22).

18 In this regard, see Van Eck \& Lombard 'Dismissal of executive directors: comparing principles of company law and labour law' 2004 TSAR 20.

19 S 71(1) of the Companies Act. 
Section 71(9) states that nothing in the section will deprive a person, that was removed from office as a director in terms of section 71, of any right that that person may have in terms of common law or otherwise to apply to court for damages or compensation. The damages or compensation envisaged in this section can be claimed for either the loss of office as a director, 20 or loss of any other office as a consequence of being removed as director. ${ }^{21}$ It is thus clear, in the event where the director is dismissed and his employment is also terminated as a result thereof, that he still has his common law remedies for damages and compensation. The Companies Act therefore, by implication, treats executive directors as employees of the company.

It must be noted that section 5 of the Companies Act, dealing with the general interpretation of the Act, states that should there be any conflict between the provisions of the Companies Act and the Labour Relations Act, the provisions of the Labour Relations Act shall prevail.

\section{Directors as Affected Persons}

If it is accepted that executive directors are employees of the company and therefore affected persons as defined in section 128 of the Companies Act, an individual director will have the right to apply for an order commencing business rescue proceedings in terms of section 131 of the Companies Act without being a shareholder or creditor of the company. This means, although directors have been excluded from the list of affected persons in their capacity as such and possibly were not intended to have the power to apply for a business rescue order, that they will have this power as employees.

Although both the definition of affected persons and, more explicitly, section 144(1) of the Companies Act make it clear that employees who are members of a registered trade union must collectively exercise their rights in terms of Chapter 6 through their trade union, it would be highly unusual for an executive director to be a member of any trade union. Executive directors, therefore, would be able to exercise their rights directly as individuals as they see fit and in their own best interests.

In The Employees of Solar Spectrum Trading 83 (Pty) Ltd $v$ Afgri Operations Limited, ${ }^{22}$ the applicants were treated rather sympathetically by the court because, as the court pointed out, as employees they did not readily have access to all the information needed to prove the requirements for a business rescue order. An executive director will obviously not get the same treatment because of his or her access to all the relevant information and must expect to be held to high standards by the court if applying for a business rescue order in the capacity of an

20 Idem s 71(9)(a).

21 Idem s 71(9)(b); own emphasis.

22 The Employees of Solar Spectrum Trading 83 (Pty) Ltd $v$ Afgri Operations Limited [2012] ZAGPPHC 359. 
employee. However, the order can still provide relief to a director who is outvoted by the other members of the board, who are not in favour of placing the company under supervision in terms of a board resolution, ${ }^{23}$ and who is concerned about the fate of the company or the potential personal liability for reckless trading if the company continues doing business while commercially or factually insolvent.

Section 131(6) contains another important provision for affected persons. Although the board is precluded from taking a resolution commencing business rescue proceedings once liquidation proceedings have been initiated by or against the company, an affected person can apply to a court for business rescue proceedings to commence even if liquidation proceedings have already been commenced. The effect of such an application is that the liquidation proceedings are automatically suspended until the application is heard. ${ }^{24}$ A director in these circumstances, therefore, could maliciously or fraudulently cause the suspension of liquidation proceedings for a substantial period, irrespective of the merits of the business rescue application.

As the applicant for a business rescue order, a director would also be the one nominating a person for appointment as the business rescue practitioner, although the nomination is subject to ratification by the independent creditors. ${ }^{25}$ This could result in the director having an undue influence on the business rescue proceedings or the actions of the rescue practitioner. This possibility position is strengthened by the power of an affected person to apply to a court for the removal of the practitioner in terms of section 130 where the practitioner was appointed by the board, and in terms of section 139 of the Companies Act in all instances.

As affected persons, directors will also have the right to participate in the hearing of an application for commencement of business rescue proceedings brought by a creditor or shareholder, and this would include the right to oppose such an application. Directors have inside knowledge of the company's financial situation and business prospects and would be in a strong position to refute allegations of financial distress or prospects of rescue on which the application is based, or at least sow doubt as to whether these requirements have been met. ${ }^{26}$

An affected person may also apply to a court for an order in terms of section 130(1) of the Companies Act setting aside the board resolution commencing business rescue proceedings, or to set aside the

\section{In terms of $\mathrm{s} 129$ of the Companies Act.}

24 Idem s 131(6).

25 Idem s 131(5). The nomination of such a business rescue practitioner must be ratified by holders of a majority of the independent creditors' voting interests.

26 In terms of s 131(4) of the Companies Act the court must be satisfied that the company is financially distressed and that there is a reasonable prospect for rescuing the company. 
appointment of the practitioner appointed by the board. An application may be made until a rescue plan has been adopted. In this section there is some hint that the legislature acknowledged the possibility of a director being an affected person, although most probably in the capacity as a shareholder or creditor: section 130(2) of the Companies Act provides that a person who, as a director, voted in favour of the resolution may not apply for the resolution or the appointment of the business rescue practitioner to be set aside unless such a person satisfies the court that the resolution was supported in good faith and based on information that subsequently turned out to be false or misleading.

In general, affected persons have the right to be notified of, and to participate in, the hearing of an application to a court to set aside a rescue resolution or replace the business rescue practitioner ${ }^{27}$ or to commence business rescue. ${ }^{28}$ These are just some of the rights of affected persons that a director, as employee, will automatically have.

\section{Special Rights of Employees}

However, it is specifically as employees that executive directors would have special and strong rights in terms of section 144 of the Companies Act that they would not otherwise enjoy.

\section{Committee of Employee's Representatives}

One of these special rights is to form a committee of employee representatives. $^{29}$ As already mentioned, employees who are represented by a registered trade union may not exercise this right themselves but must do so through their trade union. Since directors would not be represented by a trade union, each individual executive director would have this right, and would quite possibly be able to exercise a substantial degree of influence on the committee as a result of their direct involvement in the company and better knowledge of its affairs.

\section{Employment Contracts and Remuneration}

Two sections are contained in Chapter 6 of the Companies Act that emphasise the extensive rights afforded to employees. These are section 136 that deals with the effect of business rescue proceedings on employees and employment contracts and section 135 that deals with post-commencement finance.

Section 136(1) provides that employees who were employed before the commencement of business rescue proceedings must continue to be employed on the same terms and conditions unless changes occur in the

27 Idem s 130(3) - (4)

28 Idem s $131(2)-(3)$

29 Idem s 144(3)(c). 
ordinary course of attrition or the employees and company agree to different terms and conditions in accordance with applicable labour laws. ${ }^{30}$ Employment contracts are also specifically excluded from the power of a business rescue practitioner to entirely, partially or conditionally suspend or apply to a court for cancellation of any contractual obligations of the company arising during business rescue proceedings out of contracts entered into before the business rescue started. ${ }^{31}$

Interestingly enough, section $137(5)$ provides that a practitioner may apply to a court for an order removing a director from office on one of the specific grounds listed in the subsection. These grounds are limited to failure by the director to comply with a requirement contained in Chapter 6 , or an act or omission by the director obstructing the practitioner in the performance of his or her duties during business rescue. This provision means that an executive director could be removed as director by a court order, but would still be an employee with all the rights of an employee in business rescue proceedings. The practitioner would also not be able to amend the terms and conditions of employment of such a director without his consent even if he is removed from office by the court ${ }^{32}$ and would have to follow the prescribed procedures of the Labour Relations Act in order to dismiss or retrench the director. 33

In terms of section 135 , any remuneration, reimbursement or other money relating to employment that becomes due and payable by a company to an employee during business rescue proceedings and is not paid to the employee must be treated as post-commencement finance. ${ }^{34}$ The section further states, even if the company obtains postcommencement finance from any lender, that these employee claims will be paid directly after the payment of the business rescue practitioner's remuneration and expenses. ${ }^{35}$ The employee entitlements will therefore be treated as super preferent claims and will rank above the claims of post-commencement lenders - even those whose claims may be secured. Unlike the Insolvency Act, ${ }^{36}$ section 135 does not limit the period or amount of such employee claims. If directors of the company are to be treated as employees during business rescue proceedings, their unpaid salaries, bonuses and other benefits, whether reasonable or unreasonably high, would also attract super preference in terms of this section.

30 Idem s 136(1)

31 Idem s 136(2)(a).

32 Idem s 136(1)(a).

33 Idem s 136(1)(b).

34 Idem s 135(1).

35 Idem s 135(2) and 135(3).

36 Act 24 of 1936. 


\section{Submission to Creditors Before Voting on a Plan}

Another important right that directors would have in their capacity as employees, is the right to be present and to make a submission to the meeting of creditors before the creditors vote on the acceptance or rejection of a business rescue plan. ${ }^{37}$ They would not have this right as directors, and even creditors have not specifically been granted this right. The right to address the meeting will put the directors in a position in which they are able to directly influence creditors to vote for or against the plan and neither the practitioner nor the creditors will be able to prevent them from exercising this right.

\section{Proposal of an Alternative Plan and Acquiring Votes}

If a business rescue plan is rejected, employees may propose the development of an alternative plan, ${ }^{38}$ or may offer to acquire the interests of any affected persons who voted against the plan to acquire or increase their own voting rights. ${ }^{39}$ Creditors, as affected persons, may only acquire the voting interests of other creditors ${ }^{40}$ and not those voting rights of shareholders, but employees, like shareholders, may acquire both. ${ }^{41}$ However, shareholders do not have the right to propose an alternative plan unless they have the right to vote on the plan because their rights would be altered, which is not usually the case.

Section 153(1)(a)(ii) provides that if a business rescue plan is rejected, the practitioner may apply to a court to have the result of the vote set aside on the grounds that it was inappropriate. If the practitioner fails to take any action after rejection of the plan, any affected person present at the meeting may make this application to a court. ${ }^{42}$ Since the executive directors, as employees, have the right to address the creditors' meeting before voting takes place, the question arises whether they will be 'present at the meeting' as required by the subsection and thus authorised to bring such an application. Shareholders will not be present at the creditors' meeting and will presumably not have this right if the rescue plan is rejected by the creditors. This right would give executive directors very strong rights and, considering the rather surprising willingness the courts have displayed in some cases to grant such an application in spite of strong objections by major creditors, this could allow the directors to have a plan approved that favours them or buy them more time before the inevitable liquidation of the company. ${ }^{43}$

37 S 152(1)(c) read with s 144(3)(e) of the Companies Act.

38 Idem s 144(3)(g)(i).

39 Idem s 144(3)(g)(ii) read with s 153(1)(b)(ii).

40 Idem s $145(2)$ (b)(ii).

41 Idem s $144(3)$ (g)(ii).

42 Idem s 153(1)(b)(i)(bb).

43 See for example Copper Sunset Trading 220 (Pty) Ltd $v$ SPAR Group Ltd and Normandien Farms (Pty) Ltd 20146 SA 214 (LP); KJ Foods CC v First National Bank [2015] ZAGPPHC 221. 
Although directors have fiduciary duties and duties of care, skill and diligence to the company in their capacity as directors, they are released from most of these duties during business rescue proceedings if they act in accordance with the instructions of the business rescue practitioner. ${ }^{44}$ Combined with the fact that they would be acting in their capacity as employees when exercising the abovementioned rights, it would seem as if they need not take the best interests of the company into consideration when proposing an amended plan or acquiring the votes of creditors and shareholders and using those votes to approve a rescue plan.

The matter of directors who also act in the capacity of employees has been under the spotlight before. In Chillibush Communications (Pty) Ltd $v$ Johnston \& Others, the Labour Court referred to the Amazwi Power Products case where it was stated that the individual must be seen from the perspective of the capacity in which he is acting at a specific moment. The approach proposed by the Chillibush case includes the following outlook: when the individual is engaged in activities related to his duties as a director, the company's constitution and shareholders' resolutions should prescribe the way in which he acts but when the same individual is busy with obligations resulting from his employment relationship, applicable labour laws should govern his conduct. ${ }^{45}$

In the $P G$ Group case, Revelas J stated that the office and duties of a director are separate from his status as an employee, and must be distinguished. ${ }^{46}$ Therefore, it is clear that a director occupies a dual position, as a 'holder of office on the one hand and [as] an employee on the other'. ${ }^{47}$

\section{Conclusion}

It is impossible to say with any certainty whether the legislature considered the fact that directors could also be employees of the company and thus be entitled to the special rights, powers and super preferences that are given to employees in business rescue proceedings. However, in the absence of any provision clearly, or by implication, excluding executive directors from being regarded as employees, it must be assumed that they have all the rights, powers and benefits that any other employees have during business rescue proceedings, even if that position may lead to abuse of the process or have other undesirable (although possibly completely unintended and unforeseen) consequences.

44 S 137(2)(d) of the Companies Act.

45 Chillibush Communications (Pty) Ltd v Johnston \& Others supra $\mathrm{n} 14$ at par 29.

$46 P G$ Group (Pty)) Ltd $v$ Mbambo NO \& Others supra n 13 at par 26.

47 Ibid; Stevenson v Sterns Jewellers (Pty) Ltd 19867 ILJ 318 (LC). 